\title{
17
}

\section{American and British experience in Iraq and Afghanistan, 2001-04}

Dan Marston

The experience of the US and British militaries in the recent wars in Afghanistan and Iraq can be understood in five core lessons identified. ${ }^{1}$ From my perspective, these are:

- There was a lack of clear and realistic strategic debates for use of force by both countries.

- There were breakdowns in civilian-military relations in both countries.

- There were breakdowns in trust between the two key allies: the United States and United Kingdom, especially in Iraq.

- There was tactical-level reform on the battlefield by both the United States and United Kingdom; however, winning tactically on the battlefield does not equate to strategic victory.

- There were problems created by ignoring the 'mosaic of the battlefield' and attempting to apply simplistic narratives and solutions to complex scenarios.

1 Lessons are identified but not necessarily analysed, and then disseminated to the proper levels in most wars. 
Why is there a need for a critical and deep assessment of the wars? We have fought difficult wars that need to be properly analysed. All experience of war needs to be analysed and the lessons identified disseminated properly. Afghanistan and Iraq are wars, and the key lessons to take away from them are timeless and relevant to both the United States and United Kingdom for future war.

As we all know, war is extremely difficult, complex and ugly, and it always has been. The last two decades of war in Iraq and Afghanistan have been difficult, but no more complicated, I would argue, than the Roman invasion and occupation of Gaul. This chapter is based upon my work and research with US and UK officers, non-commissioned officers and soldiers, from 2006 to the present in Iraq and Afghanistan, where I engaged with 65 battalions, 27 brigades, 14 divisions, 10 corps and multiple command generals of the Multi-National Force - Iraq (MNF-I), Commander ISAF and Operation IRAQI RESOLVE. In the end, more than 80 per cent of these men and women understand and understood the need for analytical debates that dealt with the width, depth and context to understand the war they were and are engaged in.

\section{Lack of strategic debates}

The decision-making and debates for the use of force in both Afghanistan and Iraq have not been as robust as they should have been. National interest was never clearly defined by either the United States or United Kingdom throughout either campaign. Most politicians and senior military commanders did not ask the difficult questions supporting the key question: to what end? They did not consider worst-case scenarios in terms of the potential sacrifice of both the countries, as well as considering the potential destruction of the enemy and the countries we were invading. We did not honestly consider the reality that when a country uses force, it will probably mean a bloody exercise and that, for all the technological advances of weapons, people are going to be killed and maimedincluding our own soldiers, sailors, marines and airmen as well as the enemy. The silver lining to this bleak assessment is that many US and UK officers, from all levels of command, are asking key questions informed by their experiences, such as: can we define the national interest? Why have we deployed forces? Do we have a coherent strategy that is tied to national interest and to the overall question of 'to what end?' This is a key lesson identified from the experiences of the wars in Afghanistan and Iraq. 


\section{Civilian-military issues}

In both the United States and United Kingdom, civilian-military relations have broken down at different times, owing to the strain of the war and lack of clarity over strategic end states. Many within the political and military leadership blamed one another for the apparent quagmire that occurred in the summer of 2003 in Iraq. Most of the leadership on both sides of the Atlantic did not engage in robust debates before launching these wars and, by 2004 , we started to see some rifts within the leadership as the war in Iraq did not go to plan and Afghanistan appeared to be losing momentum.

By 2006 and early 2007, many policy-makers and military leaders were questioning the commitment to the wars, especially in Iraq. This was also a period where many people would accuse some of the military leadership in both countries of giving politically aware advice to policy-makers, instead of sound military advice. This was especially true in the context of the British experience in Iraq in $2007 .^{2}$

There are two high-profile examples that illustrate the apparent breakdown in relations. The first occurred in 2010, when General Stanley McChrystal resigned from his post in Afghanistan as Commander ISAF. This example highlighted an evident breakdown in communications between senior military and political leaders within the United States. The other example is from the United Kingdom, when then Chief of the Defence Staff, General Sir David Richards, had an open debate with the then British Government and people regarding the 'covenant' and the role of the military in society. ${ }^{3}$

Although many people in Britain have applauded the establishment and findings of the Chilcot (or Iraq) Inquiry, other observers point to a lost opportunity. ${ }^{4}$ Many journalists and commentators have focused

2 See some the following recent studies by Brigadier (ret'd) B. Barry, which cover some key issues for British experiences in both Iraq and Afghanistan: 'Bitter war to stabilize southern Iraq-British Army report declassified', Adelphi Series, International Institute for Strategic Studies, vol. 56, issue 461, London, 10 October 2016; and Harsh Lessons: Iraq, Afghanistan and the Changing Character of War, International Institute for Strategic Studies, London, 2017. See further H. Strachan, R. Iron and J. Bailey (eds), British Generals in Blair's Wars, Ashgate Publishing, Farnham, UK, 2013, for more detailed discussions of these issues.

3 See the following article, which hints at the tensions: C. Coughlin, 'A last salvo from General Sir David Richards', 17 July 2013, www.telegraph.co.uk/news/uknews/defence/10185613/A-last-salvofrom-General-Sir-David-Richards.html (retrieved 2 April 2020).

4 Sir John Chilcot, The Chilcot Inquiry, House of Commons Library, 1 July 2016, at commons library.parliament.uk/research-briefings/sn06215/. 
exclusively on the decision-making regarding the invasion of Iraq in 2003 while failing to address the more damning evidence relating to the difficult civilian-military debates in the post-2003 phase of the war and the many tensions and lessons identified during this period. The US debates in late 2006 and early 2007, regarding whether to 'surge' or 'not surge' in Iraq, offer a similar level of lessons and debates from which much could and should be learned.

\section{Breakdown in trust with allies}

Another major issue that occurred was the breakdown in trust between the two key allies, the United States and United Kingdom. Much of this breakdown came down to arrogance: both countries were guilty of not understanding the long-term impact of invading and occupying two different countries, Afghanistan and Iraq. Both countries discounted the impact of using force with no clear end state in either country.

Both countries were also arrogant regarding the perceived response from their respective populations. Many of the policy-makers and military commanders expected that the populations would see their militaries as liberators-an assumption in which we were very much mistaken.

The levels of arrogance and distrust between the United States and United Kingdom reached the high-water mark in Iraq. Although Britain agreed with the initial planning of the campaign, it quickly distanced itself from the breakdown of the security situation in Iraq. The British hunkered down in Multi-National Division - South East (MND-SE) and attempted to withdraw from the war as quickly as possible. As the US military and civilian organisations in Baghdad attempted to come to terms with the rise of violence from the summer of 2003, there was a growing disconnect between the two allies. The level of arrogance started to permeate the British policy and military leadership as they claimed to have pacified MND-SE and Basra in particular. Senior British military officers specifically stated that the US military had much to learn from the British expertise when dealing with the rising insurgency. ${ }^{5}$

5 An example of this: BBC News, 'UK general attacks US Iraq policy', news.bbc.co.uk/2/hi/ 6973618.stm (retrieved 3 April 2020). 


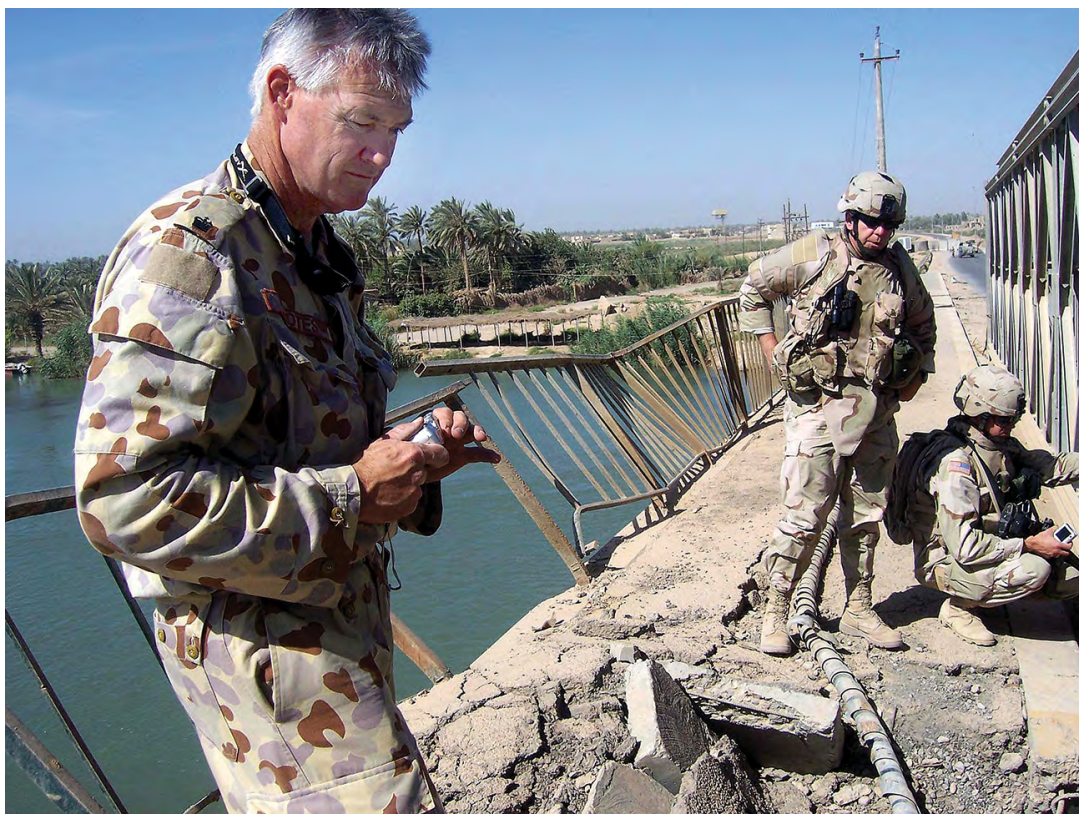

Major Cootes, Chief of Engineers on Multi-National Corps - Iraq, in 2005 surveying a bridge that was partially destroyed by a VBIED attack in 2004.

Source: Courtesy of the Department of Defence.

In 2005-06, both militaries were trying to come to terms with the occupation. Many within the British junior and mid-level leadership questioned both so-called British expertise and criticism of US efforts. Nevertheless, British media commentators and policy-makers in London continued to follow this simplistic narrative, and by 2006 the two allies were on divergent paths in Iraq. This was particularly ironic as the US military had been undergoing a major transformation to deal with the reality of the conflict they were facing. Meanwhile, British arrogance would come back to hurt them by 2008 .

Many American and British senior officers in MNF-I were doubtful about the validity of reporting from Basra by late 2007 and early 2008 . They understood that most of the 'dishonesty' coming through could be attributed to the disconnect within the British Government and the 
pressure to withdraw from an unpopular war. ${ }^{6}$ The issue is that many professional soldiers, NCOs and officers in the British Army understood that the previous narrative of 'expertise' had been incorrect, and felt that their senior command was not being honest with their US allies. In February 2007, I wrote a report after my second visit to Iraq in six months, in which I stated:

I was upset with what I saw and heard in Basra. This may sound a bit over the top, but the honour of the British Army and its reputation [are] at stake. Overall, the mood amongst many British officers is frustration. They want to be boots on the ground 24/7, like they perceive the Yanks are in the north ... Allow the boys on the ground to storm back into Basra, start up company bases with embedded Iraqis and think long term ... get the British Army thinking more about long term and less about force protection. The last thing we need is for a USMC regiment or US Army Brigade to come south in the future to do the job. Such an eventuality would be humiliating for the British Army. ${ }^{7}$

The end result was a complete breakdown between the British and Americans in Iraq. The British were withdrawing, based not upon the situation on the battlefield but upon political requirements in London. ${ }^{8}$ The culmination of this breakdown and distrust came to a head in March 2008, during Operation CHARGE OF THE KNIGHTS (CoTK). As a senior British officer stated:

The opening moves of Operation CoTK did indeed expose our lack of situational awareness and lack of resources to take the fight to the enemy. This led to the Iraqis and the Americans doubting our commitment and ability, and tarnished our reputation.'

Luckily, after this breakdown, interactions and coordination improved for the war in Afghanistan, for later operations in Iraq, and for Syria and beyond.

6 See the findings of the Iraq Inquiry for an in-depth discussion of the breakdown between the United Kingdom and the United States and the disconnect with the policy-makers in London and the field commanders in Iraq. For further details, see webarchive.nationalarchives.gov.uk/ 20171123123237/http://www.iraqinquiry.org.uk (retrieved 3 April 2020).

7 Report to MNF-I and MND-SE, February 2007 (copy held by author).

8 Daniel Patrick Marston, 'Operation TELIC VIII to XI: Difficulties of twenty-first-century command', Journal of Strategic Studies, 2019, doi.org/10.1080/01402390.2019.1672161.

9 Comments from senior British officer from Operation CoTK, 2008. 
There was also some arrogance from US Iraq War veterans after 2008, notably when they deployed to Afghanistan. Many assumed that they could apply the same tactics, techniques and procedures to the very different war in Afghanistan. Luckily, we were able to limit the influence of these attitudes and avert any serious damage. A US Marine Corps report from early 2007 was blunt in its message to Iraqi veterans:

Afghanistan is not Iraq. The people, culture, terrain, and climate, and the nature of the enemy differ greatly between the two geographic areas. Units are responsible for substantial operating areas and as a result their influence can span all the war-fighting functions as is noted by Operation Enduring Freedom veteran units ... than that found in Iraq. ${ }^{10}$

\section{Tactical reform}

One key lesson of these conflicts was that tactical reform did occur on the battlefields of Iraq and Afghanistan, for both US and British forces. Reform was generally bottom up and was slowly tied to home stations and systems, and followed time-honoured traditions of staring defeat in the face, learning from the battlefield, and wanting to win-all of which provide key lessons for the future. The process supported a transformation of units and formations to defeat the enemy-whoever that may be. The US Army, US Marine Corps and British Army tactically adapted to a war-it was not a counter-insurgency moment. ${ }^{11}$

Reform in Iraq and Afghanistan occurred within the US Army and US Marine Corps before the arrival of General David Petraeus and the publication of the US Army counter-insurgency field manual, FM 3-24. For some units and formations, it began in 2003, on the road to Baghdad. ${ }^{12}$ The Petraeus and 3-24 moment provided the needed top cover' for units, formations and commanders in both theatres-leading to a post-war narrative that is somewhat different from the reality on the ground. As many officers, non-commissioned officers and soldiers

10 Internal USMC report, 2007.

11 See my article 'Smug and complacent? Operation TELIC: The need for critical analysis', British Army Review, vol. 147, 2008, pp. 16-23, for a more detailed discussion.

12 Headquarters, Department of the Army, FM3-24 \& MCWP3.3-33.5 Insurgencies and Countering Insurgencies, Washington, DC, May 2004. One need only to look at the 1st Marine Division and 3rd Infantry Division reporting and after-action reports to see that the soldiers, NCOs and officers were quite critical of problems that occurred and the need for constant adaptation. 
attempted to come to terms with the wars in front of them, they were quite open to new ideas. The following two examples from a British officer and an American officer, both veterans of the Afghanistan war, highlight the constant assessment and debates needed within a military organisation to deal with the complexity of war.

The British officer, a veteran of the first Herrick operation (involving the deployment of British forces in Afghanistan in 2002) in Helmand Province, stated in 2006:

We must also avoid dressing COIN [counter-insurgency] up as something fundamentally new. We must be wary of losing sight of the lessons from previous campaigns ... [A]dditionally, as in previous COIN campaigns, WARFIGHTING is an element of COIN ... Many of the lessons learned from the battlegroups resulting experiences are not new. Common themes from previous UK COIN campaigns and conflicts were all evident in the operations conducted in Helmand Province. The key lesson is that we ignore previous experience of such campaigns and those of our allies at our peril. ${ }^{13}$

The US Army officer, a veteran of Regional Command East, stated in 2007:

While a population focused strategy relies heavily on non-kinetic means, it increases kinetic operations as well. 'Planting the flag' in the heart of known enemy sanctuaries dislocates the enemy both physically and psychologically. He must fight back or lose. Task Force Spartan experienced a sharp rise in combat over previous rotations, but thanks to the close combat skill and firepower of American units, killed exponentially more enemy than suffered friendly casualties. The metric of enemy dead is not useful in gauging COIN success, but it does provide insight into the degree to which a unit has separated the enemy from the populace. Killing, capturing, forcing to flee, or convincing the enemy to reconcile are all ways to achieve separation. ${ }^{14}$

These quotes give some indication that the US and British militaries were learning institutions over the course of these two wars, and could be proud of their abilities to adapt, as their fathers, grandfathers and

13 Comments from a British officer, 2008.

14 Comments from a US Army officer, 2007. 
great-grandfathers had done since the First World War. The question that remains is: have they taken these experiences and dived deep enough with critical analysis to draw some key themes for future wars?

\section{Mosaic of the battlefield}

This final theme or lesson is linked heavily with the previous lesson. Throughout the wars in Iraq and Afghanistan, there were times when policy-makers and military commanders attempted to apply 'blanket solutions' and/or narratives for the various districts and provinces in Iraq and Afghanistan and each year of the campaign without understanding the need for context. As many veterans were aware, Basra was different from Al-Anbar, which was different from Mosul in Iraq; in Afghanistan, Regional Command (RC) South was different from RC South-west, which was different from RC East. Each year of the war in Iraq and Afghanistan was different from the previous and subsequent years. This is true in all wars - a fact that many have failed to recognise when they create their narratives or so-called lessons learned.

I made this point clear to the Commanding General, International Security Assistance Force (COMISAF) in Afghanistan in 2010:

While this concept may be obvious at the COMISAF level, there is a need for clear and consistent recognition that each battalion's area of operation (AO) will have different solutions ... [a]nd that the commanders need to be allowed to develop these different solutions and pass along their knowledge. It must also be recognised and made clear that all lessons may not be applied everywhere. Each area of operation needs to be allowed to come up with their own solutions in order to succeed. There is a need to share information and lessons, but all commanders understand that [there] is no silver bullet ... Clarity in communication is essential, with due respect for the chain of command, the commanding officers of the AOs need to feel confident that they are right to use their judgement in tailoring solutions for their $\mathrm{AO} .{ }^{15}$

15 Report to COMISAF, October 2010 (copy held by author). 


\section{Final thought}

The five themes or lessons outlined here still need to be analysed and debated among the US and British policy and military leadership-before people move on to the next perceived threat. These five issues are sure to rear their heads on the next battlefield, wherever it may be, as they are timeless in history. The core reason why they need to be debated was best summed up by a former US Army General, William Sherman, who stated in 1872: 'There is many a boy here today who looks on war as all glory, but boys, it is all hell.' 
This text is taken from Niche Wars: Australia in Afghanistan and Iraq, 2001-2014, edited by John Blaxland, Marcus Fielding and Thea Gellerfy, published 2020 by ANU Press, The Australian National University,

Canberra, Australia.

doi.org/10.22459/NW.2020.17 